\title{
THE EFFECT OF NEGATIVE PRESSURE BREATHING ON URINE FLOW
}

\author{
By OTTO H. GAUER, ${ }^{1}$ JAMES P. HENRY, HERBERT O. SIEKER, AND \\ WALLACE E. WENDT \\ (From the Aero Medical Laboratory, Wright Air Development Center, \\ Wright-Patterson Air Force Base, Ohio)
}

(Submitted for publication June 10, 1952; accepted October 21, 1953)

It is known that changes of blood volume are associated with changes of urine flow. Moderate bleeding not sufficient to result in a drop of arterial blood pressure leads to oliguria. Mild plethora as induced by small transfusions of plasma (1), isooncotic albumin (2), whole blood (3), or washed red cells (4) leads to diuresis. A possible explanation of this phenomenon could be sought in a hypothetical volume regulatory mechanism using nervous elements in the vascular walls to sense "the fullness of the blood stream," which according to Peters (5) "may provoke the diuretic response on the part of the kidneys." It was hoped that, by giving due regard to the elastic properties of the circulatory system and hence to the distribution of induced volume changes, a study of the distribution of sensitive end-organs in the vascular bed might yield some hints as to the probable nature and location of a volume regulatory mechanism. While the arterial tree, due to its high volume elasticity coefficient, has to be ruled out as a potential reservoir, there is evidence that from the viewpoint of their pressure volume relations the pulmonary and venous circulation form an appropriate unit for such a function (6-8). A volume change could be measured most accurately if the whole system or one compartment of average or greater than average distensibility had stretch receptors intercalated in its walls. While little is known about stretch receptors in the peripheral veins, a variety of sensitive nervous end-organs similar to those in the carotid sinus have been found in the intrathoracic circulation, particularly in the walls of the venae cavae, the pulmonary vein and both auricles $(9,10)$. The complex physiology of the sensitive nervous endorgans in the thoracic viscera has recently been

1 Present Address: Department of Physiology and Pharmacology, Duke University School of Medicine, Durham, North Carolina. discussed in detail $(11,12)$. Centripetal nervous impulses from these regions are represented by a whole variety of signals conducted in the $\mathrm{A}, \mathrm{B}$, and $C$ fibers. If one or a combination of several groups of these signals indicate volume sense and share in the office of moderating the kidney function, it should be possible to increase and decrease urine flow by artificially increasing or decreasing the blood content of the compartments in which the sensitive end-organs are located.

Change of the filling of the intrathoracic circulatory organs can easily be achieved by application of constant positive or negative pressure breathing. Drury, Henry, and Goodman (13) have already found that positive pressure breathing impairs urine flow. They interpreted this finding as a sign of general circulatory stress. Since it is known that many kinds of stress may lead to oliguria, the evidence of any experiments which depend solely on reduction of urine flow was felt to be ambiguous. The authors, therefore, focused their efforts on the design and evaluation of an experiment which uses as the critical end point production of diuresis. This can be achieved by application of constant negative pressure breathing (NPB) at pressures of the order of $10 \mathrm{~cm}$. $\mathrm{H}_{2} \mathrm{O}$. Even if a more direct approach to test the validity of the hypothesis which stimulated these experiments were to fail, the results seemed interesting enough to merit publication.

\section{METHODS}

Over seventy experiments were performed on forty dogs, most of them females. The animals were premedicated with 0.7 to $1 \mathrm{mg}$. per $\mathrm{Kg}$. of morphine and then anesthetized with approximately $60 \mathrm{mg}$. per $\mathrm{Kg}$. of chloralose ( 1 per cent solution in .6 per cent saline). After the catheters of the pressure gauges for recording various intravascular pressures had been inserted, the narcosis was maintained at the lightest level compatible with quietude by intravenous injection of $5 \mathrm{mg}$. per $\mathrm{Kg}$. chloralose every ten minutes. In order to maintain 


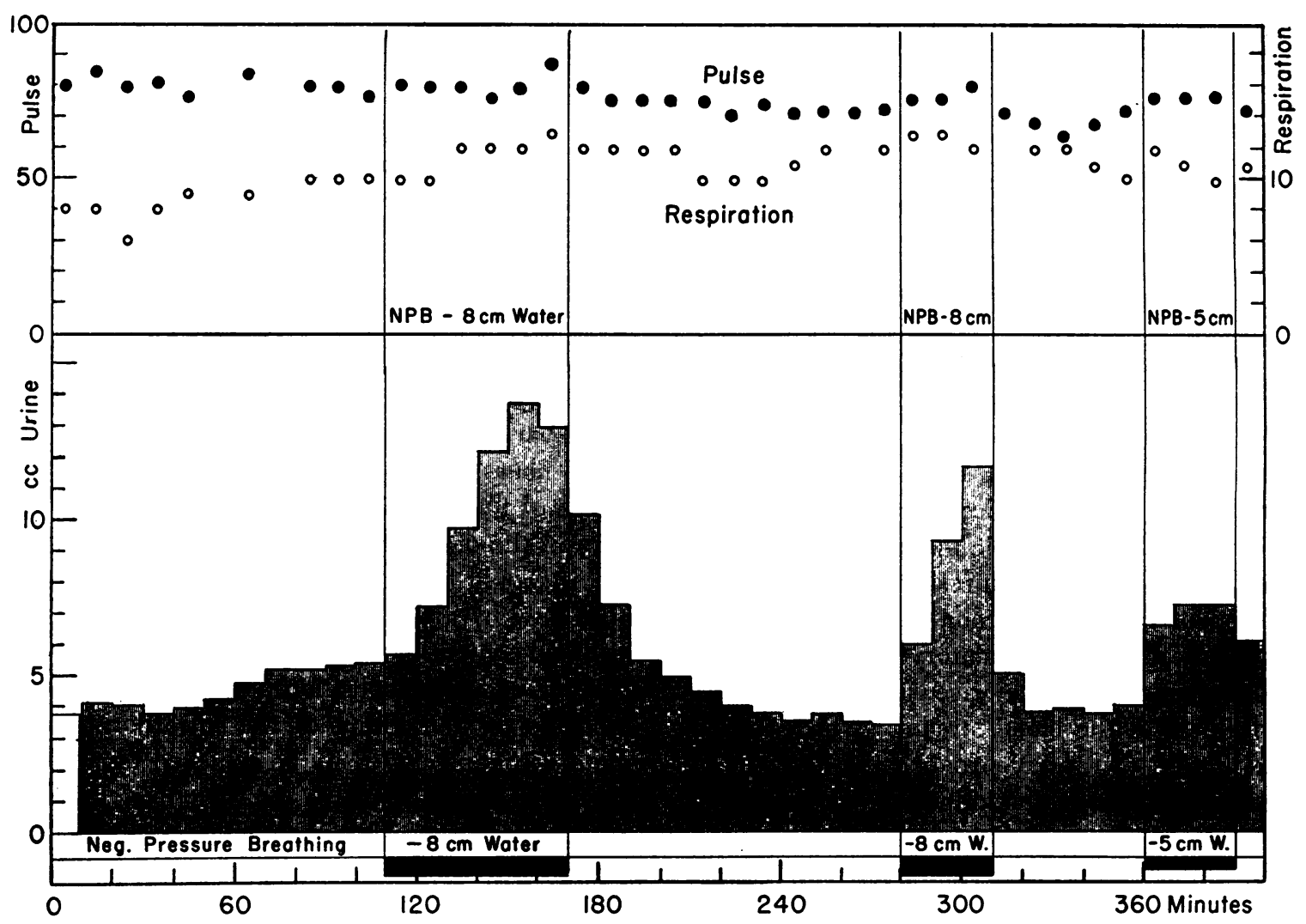

Fig. 1. Effect of Repeated Applications of NPB on Urine Flow, Pulse Rate, and Respiration

Note the slow onset of diuresis and the long after-effect. In this experiment marked increases in urine flow were observed without any substantial change in pulse and respiration rates.

proper hydration enough saline was added to the chloralose to make up a total injection of $1 \mathrm{cc}$. per $\mathrm{Kg}$. per 10 minutes of an isotonic solution. The animals were placed on their sides without restraint.

Urine was collected through an indwelling catheter in the bladder. Females were catheterized with an S shaped glass tube of $5 \mathrm{~mm}$. inside diameter; males with a tapered plastic catheter $3 \mathrm{~mm}$. inside diameter. Both catheters had several side holes around the tip. The suction of the fluid column of about $50 \mathrm{~cm}$. in the rubber tube connecting the catheter to the measuring burette on the floor was usually sufficient to keep the bladder empty at all times. In a few animals it was occasionally necessary to provoke contraction of the bladder by moving the catheter at due intervals. The urine was measured in a vertical $10 \mathrm{cc}$. narrow lumen glass burette.

Negative, and in a few instances positive, pressure breathing was accomplished in the following way. Immediately after induction of anesthesia a tracheal intubation was performed. By the use of valves close to the mouth the respiratory dead space was reduced to a minimum. The inspiratory and expiratory tubes were connected to a 20 liter container which was ventilated with fresh air by a suction pump at a rate of 160 liters per minute. As an added precaution, a $\mathrm{CO}_{2}$ absorbing cartridge was introduced in the air path. The amount of suction as indicated by a water manometer could be set by a screw clamp at the air intake. The same equipment was used for positive pressure breathing by replacing the suction pump with a source of air pressure. In one experiment for determination of cardiac output under NPB, the low breathing pressure was obtained by adding an appropriate extra weight to the counter weight of the bell of a basal metabolic spirometer (14).

Pulse rate and respiration were counted at ten minute intervals throughout all experiments. During episodes of special interest one or several of the following pressure recordings were taken continuously in individual experiments : Arterial pressure in the carotid or femoral artery with Statham gauge P23A 0-75 cm. $\mathrm{Hg}$ (15): Venous pressures in the vena cava superior and abdominal vena cava with Statham gauge $\mathrm{P} 23 \mathrm{~B} \mathrm{O}-5 \mathrm{~cm}$. $\mathrm{Hg}$ using recording galvanometers of Heiland Type $\mathrm{E}$ with no damping resistance. All mean pressures were determined by planimetry. Two cardiac output determinations by the Fick method were made in one experiment. Hematocrit changes were checked in six experiments.

It was soon suspected that the management of the ani- 
mals before the experiments and their state of hydration may influence constancy of urine flow during the control period and their sensitivity to NPB. The animals were kept for a minimum of three weeks on a liberal constant diet of dog food and horse meat. Water was offered ad libitum. They were fed for the last time on the afternoon before the experiment. The first 25 to 30 animals of the series, started early in Spring, received no prehydration. Later the animals were offered thin meat broth after the last feeding. They took about 2 liters of this broth during the evening. An alternative procedure was the addition of $1 \mathrm{Gm}$. salt per day to the regular diet. With the onset of hot summer weather urine flow became rather high and more variable when the animals were brought from the hot kennels to the air conditioned laboratory. In retrospect, it is not possible to decide whether this was due to the change of climate or to the change in experimental regime. It appears desirable, however, to avoid exposing the animals to extremes of temperature and to significant temperature differences between kennels and laboratory.

\section{RESULTS}

Figure 1 is the record of a typical experiment. After a control period of constant urine flow, application of negative pressure breathing episodes of $-8 \mathrm{~cm}$. and $-5 \mathrm{~cm}$. water produce an increase in urine excretion of between 100 and 200 per cent. The diuresis starts slowly and reaches a peak after thirty to forty minutes. After cessation of the negative pressure the urine flow returns gradually to control level. In the average animal urine flow increased from $4.4 \mathrm{cc}$. per 10 min. to 9.9 cc. per $10 \mathrm{~min}$. or from $.030 \mathrm{cc}$. per $\mathrm{Kg}$. per min. to $.066 \mathrm{cc}$. per $\mathrm{Kg}$. per min. Maximum urine excretion was usually observed at the end of the NPB period. In 6 of 21 experiments in which NPB was maintained for more than 50

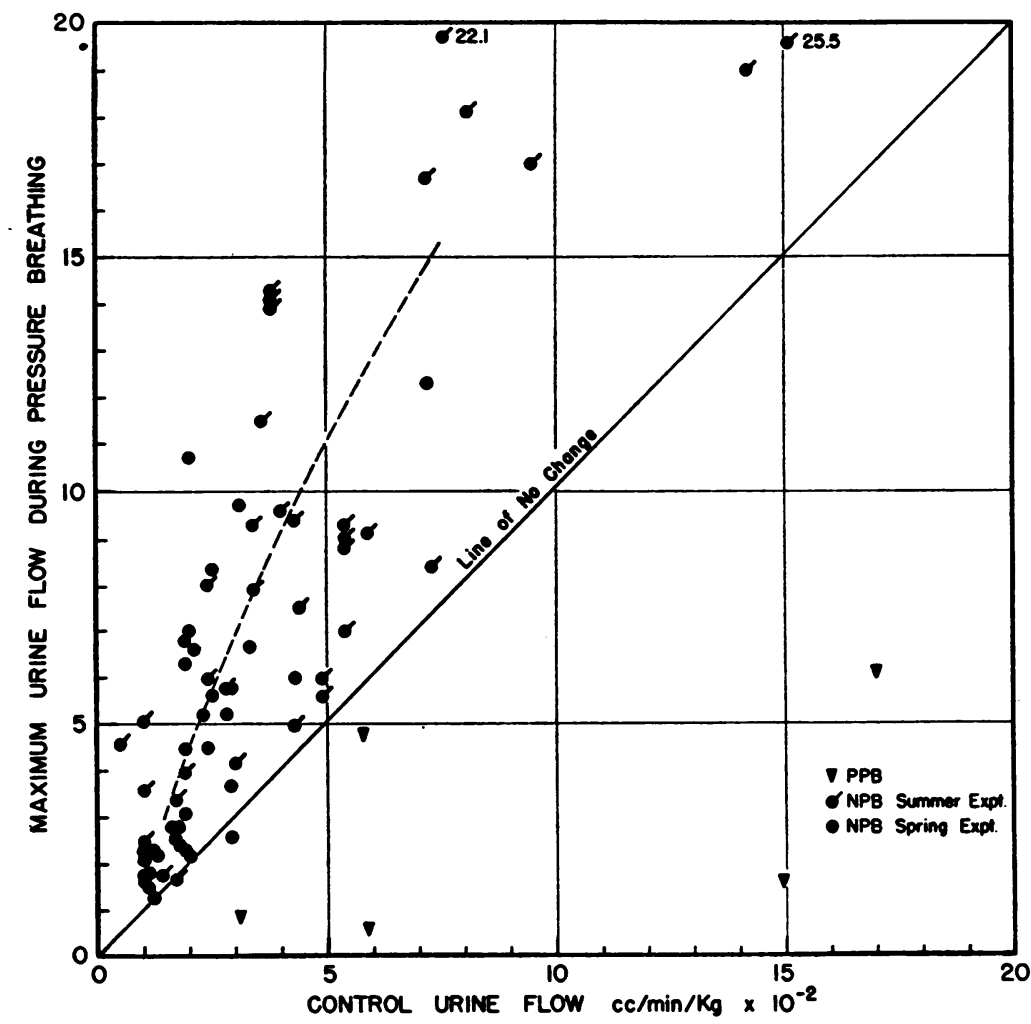

Fig. 2. Effect of Continuous Pressure Breathing on Urine Flow

Abscissa : Arithmetic mean of control flow before onset and 30 to 40 minutes after cessation of pressure breathing. Ordinate : Maximum urine flow obtained during the $\mathbf{3 0}$ to $\mathbf{4 0}$ minute pressure breathing period. Dotted line: Average urine flow with NPB. Although the sensitivity of the animals, as expressed by the ratio of urine flow with NPB over control flow, is independent of control flow, the better hydrated summer animals $\sigma$ show much greater absolute changes of urine flow than do the spring animals - Positive pressure breathing $\nabla$ results consistently in a decrease of urine flow. 
TABLE I

Mean pressure changes with $10 \mathrm{~cm}$. water $N P B$ *

\begin{tabular}{|c|c|c|c|c|c|c|c|c|c|}
\hline \multirow[b]{2}{*}{ Date } & \multicolumn{3}{|c|}{$\begin{array}{c}\text { Arterial pressure } \\
m \boldsymbol{m} . \mathrm{Hg} \\
\end{array}$} & \multicolumn{3}{|c|}{$\begin{array}{c}\text { Central venous pressure } \\
\mathrm{cm} . \mathrm{H}_{3} \mathrm{O}\end{array}$} & \multicolumn{3}{|c|}{$\begin{array}{c}\text { Peripheral venous pressure } \\
\qquad \mathrm{cm.H}, \mathrm{O}\end{array}$} \\
\hline & Before & During & After & Before & During & After & Before & During & After \\
\hline $5 / 20$ & 124 & 125 & 119 & 10.3 & +4.7 & 10.4 & 13.8 & 7.9 & 11.5 \\
\hline $5 / 25$ & 126 & 124 & 140 & 9.2 & +2.7 & 9.3 & 9.7 & 6.6 & 9.9 \\
\hline $6 / 5$ & 89 & 89 & 106 & 0.5 & -8.3 & 2.2 & & & \\
\hline $6 / 12$ & 89 & 90 & - & 3.1 & -1.9 & - & & & \\
\hline $6 / 18$ & 124 & 138 & 142 & 4.5 & -4.0 & 1.3 & & & \\
\hline $6 / 27$ & 95 & 95 & 95 & 4.0 & -6.0 & 2.0 & & & \\
\hline $6 / 29$ & $\begin{array}{l}140 \\
132\end{array}$ & $\begin{array}{l}132 \\
140\end{array}$ & $\begin{array}{l}120 \\
126\end{array}$ & $\begin{array}{r}10.4 \\
8.9\end{array}$ & $\begin{array}{l}+5.7 \\
+1.4\end{array}$ & $\begin{array}{l}9.1 \\
9.8\end{array}$ & & & \\
\hline $7 / 3$ & $\begin{array}{l}80 \\
98\end{array}$ & $\begin{array}{r}88 \\
105\end{array}$ & $\begin{array}{r}87 \\
111\end{array}$ & $\begin{array}{l}5.7 \\
7.5\end{array}$ & $\begin{array}{l}-0.7 \\
-1.6\end{array}$ & $\begin{array}{l}5.6 \\
7.1\end{array}$ & & & \\
\hline $7 / 19$ & 112 & 129 & 126 & 8.8 & 0 & 7.8 & & & \\
\hline $\begin{array}{r}7 / 20 \\
\text { (a) } \\
\text { (b) }\end{array}$ & $\begin{array}{r}95 \\
100 \\
84\end{array}$ & $\begin{array}{r}90 \\
96 \\
106\end{array}$ & $\begin{array}{l}100 \\
100 \\
124\end{array}$ & $\begin{array}{l}6.2 \\
5.4 \\
0.6\end{array}$ & $\begin{array}{r}-1.3 \\
=8.2 \\
-14.8\end{array}$ & $\begin{array}{l}5.4 \\
6.8 \\
2.7\end{array}$ & $\begin{array}{l}8.1 \\
6.9 \\
7.8\end{array}$ & $\begin{array}{l}4.5 \\
3.7 \\
3.2\end{array}$ & $\begin{array}{l}6.9 \\
9.1 \\
4.0\end{array}$ \\
\hline $7 / 23$ (a) & $\begin{array}{l}121 \\
128\end{array}$ & $\begin{array}{l}126 \\
128\end{array}$ & $\frac{128}{-}$ & $\begin{array}{l}5.5 \\
1.2\end{array}$ & $\begin{array}{l} \pm 1.4 \\
-6.5\end{array}$ & 1.2 & $\begin{array}{l}5.8 \\
1.8\end{array}$ & $\begin{array}{l}2.1 \\
0.9\end{array}$ & \\
\hline $7 / 25$ & 128 & 135 & 124 & 7.4 & -3.6 & 2.7 & 8.9 & 3.9 & 6.5 \\
\hline Mean & 111 & 115 & 117 & 6.6 & -0.8 & 5.7 & 7.9 & 4.1 & 8.0 \\
\hline Mean $\Delta \mathrm{P} . \dagger$ & & +1 & & & -7.0 & & & -3.9 & \\
\hline
\end{tabular}

* In three cases higher pressures were used, (a) $15 \mathrm{~cm} . \mathrm{H}_{2} \mathrm{O}$ and (b) $20 \mathrm{~cm} . \mathrm{H}_{2} \mathrm{O}$. The data from these experiments were not included in the calculation of the mean Central Venous Pressure. Comparison of individual figures shows that an increase in suction beyond $10 \mathrm{~cm}$. $\mathrm{H}_{2} \mathrm{O}$ is not reflected by a further fall of Peripheral Venous Pressure.

$\dagger \Delta \mathbf{P}=$ Pressure during NPB $-\frac{\text { pressure before }+ \text { pressure after NPB }}{2}$.

minutes, urine flow started to decline after a maximum was reached at about 30 to 40 minutes. However, at the end of the NPB period urine flow was still considerably higher than the control level and fell sharply when the NPB was discontinued. In 24 experiments, urine flow did not return to normal with cessation of NPB but remained about 30 per cent above control level. In four cases it remained equal to or went even higher than the highest value with NPB. This response pattern cannot, of course, be distinguished from a spontaneous diuresis.

Figure 2 is a survey of $70 \mathrm{NPB}$ tests and 5 positive pressure breathing (PPB) applications. The abscissa indicates control flow in cc. per minute and $1 \mathrm{Kg}$. of dog weight. It represents the arithmetic mean of the control flow before onset of pressure breathing and control flow 30 to 40 minutes after cessation of pressure breathing. The ordinate gives maximum urine flow during pressure breathing. There is only one experiment with no change and two with a very slight decrease of urine flow with NPB. These figures stem from the above-mentioned four experiments in which urine flow continued to rise after cessation of NPB. The average urine flow during NPB is expressed by the dotted line whose relative linearity indicates that the per cent increase remains approximately constant regardless of control flow. It is, however, obvious that the control flow and absolute change of urine flow during NPB is much greater in the summer animals. Since the degree of prehydration was changed between the seasons it is not possible to decide whether this increase was due to the change of climate or to the experimental regime. The application of positive pressure breathing in five experiments resulted in a marked decrease of urine flow. 
The average blood pressure was $114 \mathrm{~mm} . \mathrm{Hg}$. It did not change with NPB (Table I). The average pulse rate was 71 . The majority of the animals showed marked respiratory arrhythmia of the heart. Immediately following onset of NPB, heart rate increased almost instantaneously and established a higher level at an average of 92 . The individual per cent increases of heart rate ranging from 0 to 92 per cent were plotted against per cent increase of urine flow. No quantitative relation between the two sets of observations could be established. There was also no relation between the individual increase of urine flow and the increase of the rate of respiration, which on the average, tripled with the onset of NPB.

Application of $10 \mathrm{~cm}$. NPB decreased central venous pressure by an average of $7.0 \mathrm{~cm} . \mathrm{H}_{2} \mathrm{O}$. The pressure in the abdominal veins fell only 3.9 cm. $\mathrm{H}_{2} \mathrm{O}$ (Table I).

Two determinations of cardiac output with the Fick method yielded an increase of 7.7 and 12 per cent. The hemotocrit was unaltered by NPB.

\section{DISCUSSION}

The relatively slow heart rate and marked respiratory arrhythmia of the pulse which is characteristic of the normal resting dog was maintained in the majority of the animals. Thauer and Wezler (16) showed that chloralose reduces but does not abolish this sign of near normal circulatory reactivity while other anesthetics, especially

TABLE II

Acute procedures changing urine flow *

\begin{tabular}{|c|c|c|c|c|}
\hline Procedure & $\begin{array}{l}\text { Urine } \\
\text { flow }\end{array}$ & $\begin{array}{l}\text { Filling of intra- } \\
\text { thoracic circulation }\end{array}$ & $\begin{array}{l}\text { Filling of extra- } \\
\text { thoracic circulation }\end{array}$ & $\begin{array}{l}\text { Pressure in renal } \\
\text { veins }\end{array}$ \\
\hline Hemorrhage (1) & Reduced & Reduced $(7,8)$ & Reduced & Reduced \\
\hline $\begin{array}{l}\text { Pos. pressure breathing } \\
\text { in humans (13) }\end{array}$ & Reduced & Reduced (38) & Increased (38) & $\begin{array}{l}\text { Increased, partly } \\
\text { counterbalanced by } \\
\text { intra abd. pressure }\end{array}$ \\
\hline $\begin{array}{l}\text { Pos. pressure breathing } \\
\text { in anesth. dogs }\end{array}$ & Reduced & Reduced (37) & Increased & $\begin{array}{l}\text { Increased (14) } \\
10 \mathrm{~cm} . \mathrm{H}_{2} \mathrm{O}\end{array}$ \\
\hline $\begin{array}{l}\text { Balloon in inf. } v \text {. cava } \\
\text { above renal veins }\end{array}$ & Reduced & Reduced & $\begin{array}{l}\text { Increased in legs } \\
\text { and lower abd. }\end{array}$ & $\begin{array}{l}\text { Increased (29) } \\
26 \mathrm{~cm} . \mathrm{H}_{2} \mathrm{O}\end{array}$ \\
\hline $\begin{array}{l}\text { Balloon in inf. v. cava } \\
\text { below renal veins (29) }\end{array}$ & Reduced & Reduced & $\begin{array}{l}\text { Increased in legs } \\
\text { and lower abd. }\end{array}$ & Reduced \\
\hline Orthostasis $(41,42,43)$ & Reduced & Reduced (44) & Increased in legs & Increased \\
\hline $\begin{array}{l}\text { Sequestering of blood } \\
\text { by cuffs ( } 46 \text { ) }\end{array}$ & Reduced & Reduced (47) & Increased in limbs & Reduced \\
\hline $\begin{array}{l}\text { Sequestering of blood by } \\
\text { cuffs plus infusion of } \\
1500 \text { cc. of blood ( } 48 \text { ) }\end{array}$ & Normal & $>$ Normal ? & $\begin{array}{l}\text { Increased in limbs, } \\
\text { normal or slightly } \\
\text { increased in abdomen }\end{array}$ & $>$ Normal ? \\
\hline Blood transfusion $(1,2,3)$ & Increased & Increased $(7,8)$ & Increased & Increased \\
\hline $\begin{array}{l}\text { Neg. pressure breathing } \\
\text { in humans }(35)\end{array}$ & Increased & Increased & Reduced & Reduced \\
\hline $\begin{array}{l}\text { Neg. pressure breathing } \\
\text { in anesth. dogs }\end{array}$ & Increased & Increased (37) & Reduced & $\begin{array}{l}\text { Reduced } \\
-4 \mathrm{~cm} . \mathrm{H}_{2} \mathrm{O}\end{array}$ \\
\hline Head down tilt (45) & Increased & Increased & Reduced & Reduced \\
\hline $\begin{array}{l}\text { Immersion of trunk in } \\
\text { warm bath }(40)\end{array}$ & Increased & Increased & Reduced & $\begin{array}{l}\text { Increased, } \\
\text { counterbalanced by } \\
\text { intra abd. pressure }\end{array}$ \\
\hline Exposure to cold (49) & Increased & Increased (50) & Reduced & Increased \\
\hline
\end{tabular}

* Only those statements with a reference number have been substantiated by direct experiments. The other statements have been deduced from the physiology of blood distribution, blood reservoirs (6) and pressure volume relationships in the extra-arterial circulation $(7,8)$. 
the barbiturates, usually produce a fast, unvarying pulse. With regard to its effect on the kidney, chloralose does not share in the antidiuretic action of other anesthetics and H. Smith (17) recently pointed out that when chloralose anesthesia was employed in water diuresis experiments "apparently maximal diuresis could be obtained with no complications." In the present work, 0.7 to 1.0 $\mathrm{mg}$. per $\mathrm{Kg}$. morphine given early in the morning was sufficient to prevent chloralose hyper-reflexia for the duration of the experiment. This dose is considerably less than the 2.5 to $5 \mathrm{mg}$. per $\mathrm{Kg}$. usually employed to demonstrate the antidiuretic effect of this drug (18) and approximates the minimal dose necessary to produce antidiuresis (19). The control urine flow of $.030 \mathrm{cc}$. per $\mathrm{Kg}$. per minute for the average $15 \mathrm{Kg}$. dog is nearly double the normal urine flow as determined in conscious animals (20). It may still appear low in view of the hydration induced by the experimental regime. However, the spring animals received no prehydration. Further, the injection of isotonic solutions, an unavoidable necessity for the induction and maintenance of anesthesia, has no direct effect on urine flow (17).

The first negative pressure breathing episode of Figure 1 is not only representative with regard to the average increase of urine flow in our 70 experiments, but also shows the characteristic pattern. While central venous pressure, heart rate and respiration, change immediately with the onset and usually stay constant for the period of NPB, urine excretion may increase only a little in the first ten minutes, then rise faster and finally level off to a maximum after 30 to 50 minutes. The return to normal is gradual and takes about 20 to 30 minutes. The slow onset of the diuresis and the long after effect could be explained on the theory that impulses from receptors in the thoracic region are transmitted to the central nervous system. There they would cause an inhibition of secretion of antidiuretic hormone with a resultant diuresis of the type observed. The experiments of Brun, Knudsen, and Raaschou who adduced strong evidence that the oliguria of orthostasis is due to release of $\mathrm{ADH}$, support such a hypothesis (21). Before a rather involved reflex mechanism of this kind can be given more serious consideration, it is necessary to determine whether hemo- dynamic or respiratory changes, brought about by NPB could directly cause the increased urine flow.

Rein (22) showed in 1931 that gross disturbances of the systemic circulation such as those induced by carotid sinus stimulation did not affect renal blood flow, although the femoral and splanchnic arteries simultaneously showed strong constriction. Subsequently, numerous investigators with different methods and approaches have found that marked changes of cardiac output or arterial pressure had relatively little effect on kidney blood flow and urine excretion (23-26). C. Heymans (27) recently commented that the renal circulation does not participate in the moment-to-moment homeostasis of general blood pressure. But even if moderate changes of cardiac output or peripheral resistance were to affect urine excretion, the changes of hemodynamics of the arterial system with the degree of NPB employed in our experiments were so small that they could not be held responsible for our results. The opinion that constant NPB should increase venous return and hence cardiac output has been disproved by Holt (14). He showed that the resultant great pressure gradient towards the heart is due to an increased flow resistance caused by a partial collapse of the upper abdominal vena cava rather than an increased venous flow. Using both the Fick principle and the dye injection method, he found with $16 \mathrm{~cm} . \mathrm{H}_{2} \mathrm{O} \mathrm{NPB}$ an increase of cardiac output of $13 \pm 16$ per cent and $4 \pm 6$ per cent, respectively, the dye figures seeming to be the more reliable ones. No perceptible change of cardiac output could be detected when using $8 \mathrm{~cm}$. $\mathrm{H}_{2} \mathrm{O}$ NPB. Although there was no doubt of the validity of Holt's careful studies, two Fick determinations were made. Yielding an increase of 7.7 per cent and 12 per cent, they were in full agreement with his findings.

The heart rate, as the most sensitive circulatory parameter, may almost double in some experiments, but no quantitative relationship between the change of heart rate and urine excretion could be established. The question has been raised whether the drop of the peripheral venous pressure may not be in part responsible for the increased urine flow. Although specific evidence on the effect of a reduction of renal venous pressure is not available, the data on the effects of obstructing outflow from the renal veins show a remarkable insensitivity of 
the kidney to this parameter $(28,29)$. In other studies (30) of the effect of local venous congestion on renal function, only one case showed a small response to pressures of the order of 10 to $20 \mathrm{~cm} . \mathrm{H}_{2} \mathrm{O}$. It required an elevation of renal venous pressure by 30 to $40 \mathrm{~cm}$. $\mathrm{H}_{2} \mathrm{O}$ to reduce the urine flow by 25 per cent. If we accept the hypothesis of Swann, Montgomery, and Lowry (31) that the remarkably "high setting" of the renal interstitial pressure of approximately $30 \mathrm{~cm}$. $\mathrm{H}_{2} \mathrm{O}$ guards the kidney against the effects of random changes of vena cava pressure unless they exceed this value, it seems unlikely, that the fall of peripheral venous pressure of $3.9 \mathrm{~cm} . \mathrm{H}_{2} \mathrm{O}$ observed in our experiments was connected with the average increase of urine flow of more than 100 per cent.

The contrast between the almost instantaneous adjustment of circulation and respiration to NPB and the sluggish response of urine excretion can be taken as added evidence against the assumption that a change of renal circulation is the immediate cause of the observed phenomenon. On the other hand, a change of blood chemistry due to the changes of respiration, which were observed in many NPB experiments, could induce this same characteristic pattern of urine excretion. It is known that a decreased arterial oxygen saturation as well as hyperventilation may lead to diuresis. However, the threshold of these effects is far in excess of that which can be anticipated in our experiments. Stickney, Northup, and Van Liere (32) had to reduce the oxygen content of the inspired air to 9 to 11 per cent before urine excretion increased by 50 per cent. Collip and Backus' (33) subjects doubled their urine output during forced respiration, which led to tetanus and dizziness and resulted in a gross increase of urine alkalinity. In the experiments of McCance and Widdowson (34) on hyperventilation in humans, sodium and potassium excretion were greatly increased. There was no relationship between the change of respiratory rate and urine flow in our experiments and it should be noted in Figure 1 that marked diuresis could be observed repeatedly with slight or inconsistent changes of respiration. Proof that alkalosis from hyperventilation was not the cause of diuresis with NPB was furnished by human experiments. It was found that unanesthetized subjects may respond to NPB with a ten-fold in- crease of urine flow without any alteration in respiratory rate, in the urine $\mathrm{pH}$ or in the total sodium and potassium excretion (35). Further evidence that alkalosis is not the causative agent is seen in recent findings (36) where in humans a marked diuresis was observed resulting from hyperventilation of a 5 per cent $\mathrm{CO}_{2}$ mixture. These authors agree that this diuresis may well be initiated by a mechanical stimulus rather than a chemical one.

The most obvious effect of NPB on the circulation consists of an engorgement of the heart and lung region (37-39). Directing our attention to the combination of increased filling of the intrathoracic circulation with increased urine flow and decreased filling of the pulmonary circulation with oliguria, we find that the described phenomenon is only one of a large number of observations in which this concurrence can be observed as a result of very different physiological events. Such events which lead to a change of urine flow have been listed in Table II. The similarity of the effects of different experiments quoted is well expressed by Adolph and Molnar (49) who state that "the diuresis can be turned on and off either by change of exposure from cold to comfortable or by change of posture from lying to standing" (Table II).

When looking for the probable nature and location of the sensitive end-organs of a mechanism linking changes of blood volume or blood distribution with urine flow, the coincidence of reduced urine flow with reduced filling of the intrathoracic organs and of engorgement of these regions with increased urine flow, is striking. On the other hand, the behavior of urine flow is not consistently related with the filling of the extra-thoracic vascular bed or the behavior of local renal venous pressure or renal congestion. It is intriguing to speculate that the apparently fortuitous similarity of reaction of the kidney to stimuli as different as gravitation and cold stress may eventually be traced back to the same hemostatic reflex originating from the circulatory organs within the chest.

There are more examples of the rule that engorgement of the pulmonary circulation coincides with increased urine flow in normal subjects. The fact that this relation is grossly disturbed in congestive heart failure could tentatively be interpreted as an impairment of sensitivity of the 
proposed volume regulatory mechanism. This concept concurs with the view held by McLean (51) who considered edema to be a problem in physiological regulation and described it as "a perversion of the regulatory mechanism of volume." Such an assumption that a circulatory reflex mediated through stretch receptors may change its sensitivity and eventually result in a "perversion" of its normal function has been proved for the carotid sinus reflex by Palme (52, 53). He found that dabbing of the pressure sensitive area with dilute adrenaline solutions or stimulation of a sympathetic fibre running into the carotid sinus reduced the sensitivity of the reflex and finally abolished it. Recent investigations (54-56) confirmed this important observation and concluded that the state of contraction (sympathetic tone) of the vascular walls which carry vaso-sensitive elements determine their mode of action. Since it is generally believed that vascular tone is increased in congestive failure (57-59) one may consider that the sensitivity of the volume regulatory mechanism is decreased leading to fluid retention in spite of pulmonary congestion.

\section{SUM MARY}

1. In seventy experiments, forty dogs were exposed to periods of constant negative pressure breathing of the order of $-10 \mathrm{~cm} . \mathrm{H}_{2} \mathrm{O}$. This stimulus consistently increased urine flow from an average of $.030 \mathrm{cc}$. per $\mathrm{Kg}$. per $\mathrm{min}$. to .066 cc. per $\mathrm{Kg}$. per min.

2. Physiological factors such as mean arterial pressure, heart rate, cardiac output, venous pressure and respiration, which are affected by negative pressure breathing or considered to influence renal function, were surveyed. No relation between urine flow and any one of these parameters could be found.

3. The most outstanding effect of negative pressure breathing is a disturbance of blood distribution. With regard to this hemostatic imbalance, diuresis with negative pressure breathing is only one of many conditions in which, in normal subjects, an engorgement of the intrathoracic circulatory organs, no matter how induced, coincides with increased urine flow.

4. As a working hypothesis, it is suggested that stretch receptors in the pulmonary circulation and/ or the chambers of the heart and the great veins may represent the sensitive part of a mechanism linking hemostatic events with urine excretion for the control of plasma volume.

\section{REFERENCES}

1. Henry, J. P., and Gauer, O. H., Certain hemodynamic factors concerned with control of blood volume. Federation Proc., 1951, 10, 62.

2. Welt, L. G., and Orloff, J., The effects of an increase in plasma volume on the metabolism and excretion of water and electrolytes by normal subjects. J. Clin. Invest., 1951, 30, 751.

3. Borst, J. G. G., The maintenance of an adequate cardiac output by the regulation of the urinary excretion of water and sodium chloride; an essential factor in the genesis of oedema. Acta. med. Scandinav., 1948, Suppl. 207.

4. Weech, A. A., The significance of the albumin fraction of serum. Bull. New York Acad. Med., 1939, $15,63$.

5. Peters, J. P., Body water. The Exchange of Fluids in Man. Springfield, Ill., Charles C. Thomas, 1935, p. 287.

6. Sjöstrand, T., The regulation of the blood distribution in man. Acta. physiol. Scandinav., 1952, 26, 312.

7. Henry, J. P., Gauer, O. H., Sieker, H. O., and Wendt, W. E., The effect of small blood volume changes on intrathoracic vascular pressures and urine flow. In preparation.

8. Gauer, O. H., Sieker, H. O., and Henry, J. P., The effect of small blood volume changes on the central venous pressure in humans. In preparation.

9. Nonidez., J. F., Identification of the receptor areas in the venae cavae and pulmonary veins which initiate reflex cardiac acceleration (Bainbridge's reflex). Am. J. Anat., 1937, 61, 203.

10. Nonidez, J. F., Studies on the innervation of the heart. II. Afferent nerve endings in the large arteries and veins. Am. J. Anat., 1941, 68, 151.

11. Whitteridge, D., Multiple embolism of the lung and rapid shallow breathing. Physiol. Rev., 1950, 30, 475.

12. Schaefer, H., Elektrophysiologie der Herznerven. Ergebn. d. Physiol., 1950, 46, 71.

13. Drury, D. R., Henry, J. P., and Goodman, J., The effects of continuous pressure breathing on kidney function. J. Clin. Invest., 1947, 26, 945.

14. Holt, T. P., The effect of positive and negative intrathoracic pressure on cardiac output and venous pressure in the dog. Am. J. Physiol., 1944, 142, 594.

15. Statham Laboratories, Beverly Hills, California, Physiological Pressure Transducers. Bull. 313.

16. Thauer, R., and Wezler, K., Die Kreislaufwirkung der gebräuchlichsten tierexperimentellen Narkotika. Arch. f. exper. Path. u. Pharmakol., 1942, 200, 84. 
17. Smith, H. W., The Kidney. Structure and Function in Health and Disease. New York, Oxford Univ. Press, 1951.

18. De Bodo, R. C., The antidiuretic effect of morphine, and its mechanism. J. Pharmacol. \& Exper. Therap., 1944, 82, 74.

19. Bonsmann, M. R., Uber Einwirkung von Opiumderivaten auf die Diurese des Hundes sowie Beobachtungen über Gewöhnung an diese. Arch. f. exper. Path. u. Pharmakol., 1930, 156, 145.

20. Adolph, E. F., Physiological Regulations. Lancaster, Pa., The Jaques Cattell Press, 1943.

21. Brun, C., Knudsen, E. O. E., and Raaschou, F., Kidney function and circulatory collapse. Post-syncopal oliguria. J. Clin. Invest., 1946, 25, 568.

22. Rein, H., Vasomotorische Regulationen. Ergebn. d. Physiol., 1931, 32, 28.

23. Selkurt, E. E., The relation of renal blood flow to effective arterial pressure in the intact kidney of the dog. Am. J. Physiol., 1946, 147, 537.

24. Post, R. S., Decrease of cardiac output by acute pericardial effusion and its effect on renal hemodynamics and electrolyte excretion. Am. J. Physiol., 1951, 165, 278.

25. Van Slyke, D. D., Effects of hemorrhage on the kidney. Ann. New York Acad. Sc., 1948, 49, 593.

26. Epstein, F. H., Post, R. S., and McDowell, M., The effect of an arteriovenous fistula on renal hemodynamics and electrolyte excretion. J. Clin. Invest., 1953, 32, 233.

27. Heymans, C., Introduction to the Regulation of Blood Pressure and Heart Rate. Springfield, Ill., Charles C. Thomas, 1950.

28. Selkurt, E. E., Hall, P. W., and Spencer, M. P., Response of renal blood flow and clearance to graded partial obstruction of the renal vein. Am. J. Physiol., 1949, 157, 40.

29. Farber, S. J., Alexander, J. D., and Eichna, L. W., Renal hemodynamics and salt and water excretion during induced congestion of the inferior vena cava of man. J. Clin. Invest., 1951, 30, 638.

30. Blake, W. D., Wégria, R., Keating, R. P., and Ward, $H$. P., Effect of increased renal venous pressure on renal function. Am. J. Physiol., 1949, 157, 1.

31. Swann, H. G., Montgomery, A. V., and Lowry, J. S., Effect of renal venous occlusion on intra-renal pressure. Proc. Soc. Exper. Biol. \& Med., 1951, 76, 773.

32. Stickney, J. C., Northup, D. W., and Van Liere, E. J., The effect of anoxic anoxia on urine secretion in anesthetized dogs. Am. J. Physiol., 1946, 147, 616.

33. Collip, J. B., and Backus, P. L., The effect of prolonged hyperpnoea on the carbon dioxide combining power of the plasma, the carbon dioxide tension of alveolar air and the excretion of acid and basic phosphate and ammonia by the kidney. Am. J. Physiol., 1920, 51, 568.

34. McCance, R. A., and Widdowson, E. M., The response of the kidney to an alkalosis during salt deficiency. Proc. Roy. Soc., London, s. B., 1936, 120, 228.
35. Sieker, H. O., Gauer, O. H., and Henry J. P., The effect of negative pressure breathing on renal function. J. Clin. Invest., 1952, 31, 662.

36. Barbour, A., Bull, G. M., Evans, B. M., Hughes Jones, N. C., and Logothetopoulos, J., The effect of breathing 5 to $7 \%$ carbon dioxide on urine flow and mineral excretion. Clin. Sc., 1953, 12, 1.

37. Böhme, W., Uber den aktiven Anteil des Herzens an der Förderung des Venenblutes. Ergbn. d. Physiol., 1936, 38, 251.

38. Fenn, W. O., Otis, A. B., Rahn, H., Chadwick, L. E., and Hagnauer, A. H., Displacement of blood from the lungs by pressure breathing. Am. J. Physiol., 1947, 151, 258.

39. Ochsner, A., Jr., Effects of pulmonary blood flow and distension on the capacity of intrapulmonary vessels. Am. J. Physiol., 1952, 168, 200.

40. Bazett, H. C., Thurlow, S., Crowell, C., and Stewart, W., Studies on the effect of baths on man. II. The diuresis caused by warm baths, together with some observations on urinary tides. Am. J. Physiol., 1924, 70, 430.

41. White, H. L., Rosen, I. T., Fisher, S. S., and Wood, G. H., The influence of posture on renal activity. Am. J. Physiol., 1926, 78, 185.

42. Epstein, F. H., Goodyer, A. V. N., Lawrason, F. D., and Relman, A. S., Studies of the antidiuresis of quiet standing: The importance of changes in plasma volume and glomerular filtration rate. $\mathrm{J}$. Clin. Invest., 1951, 30, 63.

43. Strauss, M. B., Davis, R. K., Rosenbaum, J. D., and Rossmeisl, E. C., "Water diuresis" produced during recumbency by the intravenous infusion of isotonic saline solution. J. Clin. Invest., 1951, 30, 862.

44. Hamilton, W. F., and Morgan, A. B., Mechanism of the postural reduction in vital capacity in relation to orthopnea and storage of blood in the lungs. Am. J. Physiol., 1932, 99, 526.

45. Wilkins, R. W., Bradley, S. E., and Friedland, C. K., The acute circulatory effects of the head-down position (negative-g) in normal man, with a note on some measures designed to relieve cranial congestion in this position. J. Clin. Invest., 1950, 29, 940.

46. McWhorter, R. L., Estes, E. H., Fitzhugh, F. W., Jr., and Merrill, A. J., Effect of pooling blood in extremities on cardiac output and renal function in man. Am. J. Physiol., 1949, 159, 580.

47. Estes, E. H., and McWhorter, R. L., Induced variations in pulmonary arterial pressure in man. Am. J. Physiol., 1949, 159, 568.

48. Judson, W. E., Hatcher, J. D., Halperin, M. H., and Wilkins, R. W., Further studies on the antidiuresis and decrease in sodium excretion during venous congestion of the limbs: Its prevention in normal subjects by a large transfusion; its absence or presence in cardiac patients with or without congestive failure. J. Clin. Invest., 1952, 31, 642. 
49. Adolph, E. F., and Molnar, G. W., Exchanges of heat and tolerances to cold in men exposed to outdoor weathcr. Am. J. Physiol., 1946, 146, 507.

50. Glaser, E. M., The effects of cooling and warming on the vital capacity, forearm and hand volume, and skin temperature of man. J. Physiol., 1949, 109, 421.

51. McLean, F. C., Edema as a problem in physiological regulation. Physiol. Rev., 1925, 5, 618.

52. Palme, F., Zur Funktion der branchiogenen Reflexzonen für Chemo- und Pressoreception. Z Ztschr. f. d. ges. exper. Med., 1944, 113, 415.

53. Palme, F., The functional mechanism of the branchiogenic reflex zones in Chapter IV-Results of recent investigations of respiration during acute and chronic hypoxia in German Aviation Medicine, World War II, prep. under the auspices of the Surgeon General, U. S. Air Force, Dept. of the Air Force, Supt. of Documents, U. S. Gov't. Printing Office, Washington, D. C., 1950, vol. 1, p. 202.
54. Heymans C., and van den Heuvel-Heymans, G., New aspects of blood pressure regulation. Circulation 1951, 4, 581.

55. Landgren, S., On the excitation mechanism of the carotid baroceptors. Acta. physiol. Scandinav., 1952, 26, 1.

56. Landgren, S., The baroceptor activity in the carotid sinus nerve and the distensibility of the sinus wall. Acta. physiol. Scandinav., 1952, 26, 35.

57. McMichael, J., and Sharpey-Schaefer, E. P., The action of intravenous digoxin in man. Quart. J. Med., 1944, n.s. 13, 123.

58. Stead, E. A., Jr., Warren, J. V., and Brannon, E. S., Effect of Lanatoside $C$ on the circulation of patients with congestive failure. A study using catherization of the right side of the heart. Arch. Int. Med., 1948, 81, 282.

59. Eichna, L. W., and Taube, H., The effect of intravenously administered digoxin and ouabain on the systemic venous pressure of patients with congestive heart failure. Am. Heart J., 1944, 27, 641. 